（4）ドラムカッタ用ピックの使用状況と新たな試み

1. は じめに

当鉱は三池炭田の最南端に位し，現在の採掘区域は，SL- 600 $\mathrm{m}$ 付近で有明海の海底炭鉣である。

稼行炭層は三池本層, 上層, 第 2 上層と賦存する累層の中から $\mathrm{S} 48$ 年より, 上層のみを採掘している。

山丈は $2.4 \mathrm{~m}$ 程度で大量出炭には好条件であつたが， S 51 年こ ろより深部移行にともない薄層化し, 現状 $1.8 \mathrm{~m}$ 程度, ところに よつては $1.4 \mathrm{~m}$ 以下の区域すら出現するようになつた。

採掘方式は長壁式後退払で, 採炭機械はダブルレンジングドラ ムカッタを使用している。

このカッタ用の裂砕ピックは, 高価で使用量が多いため, 稼行 炭層の条件次第では出炭原価に大きな影響を及ぼすことがある。

当鉱の場合，好条件に恵まれた時期は大した問題とはならなか つたが, 薄層化し, 隆起盤が出現してからは, にわかにコストア ップとなつてきた。

しかも，この傾向は $S 52$ 年に至りさらに悪化し，ピック使用料 100 円 $/ \mathrm{t}$, 総額で 1 億円/期に達するようになつた。一方将来の 採掘フイルドはさらに悪条件が予想された。

ここに至り裂砕ピックの技術面, すなわち, 材質, 形状, 加工 方法, 熱処理, 修理方法等の再検討が必要となり, さらに降下量, 現場管理, 使用方法, 回収など管理面の強化がせまられ, この両 面から努力を重ねた。

この結果, その後の採掘条件の悪化にもかかわらず, S 53年上 期, 下期と逐次コストの低下が実現できた。ここでは, この経緯 と成果についての大略を報告する。

なお, 本命題の技術面については, ピックメーカである亀山ビ ッド社の絶大な協力により推進できた次第である。

\section{2. 使用経過と改善の経続}

ドラムカッタは周知の通り, イギリスの炭銨で発達し, その後 西独などを経て, わが国に輸入された機械であるが, 当鉱の場合 三池炭鉱の他山で使用されていた時期でも, なおホーベル採炭を 続けており，S44 年, シールド枠 (以下 $S \cdot D$ 方式) 導入時にや つと採用したので相当遅れをとつていた。したがつてピックにつ いても, かなりの変遷や研究がなされてきているはずであるが, 当鉱の場合すでに, 三池製作所 (以下三作) は $\mathrm{HD}-86$ 型 ( 第 1 図参照) の技術を持つており，その指導のもとに開始したのであ

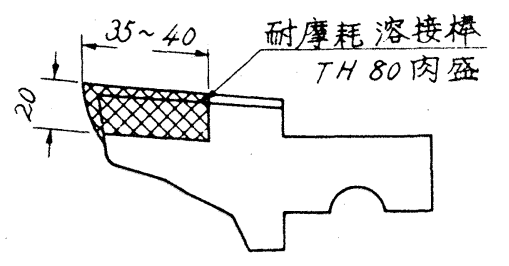

第 1 図

HD- 86 型 カッタピック (単位: $\mathrm{mm}$ )

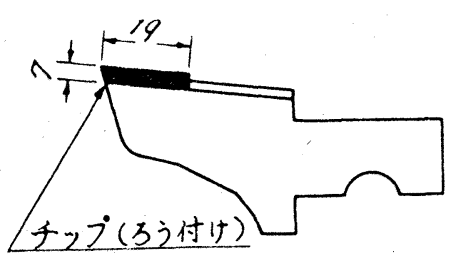

第2図

旧型チップ付

ピック

( 単位 : mm )

る。

一応 S D方式が地についた S $46 \sim 47$ 年ごろには, ドラムのピ ック配列や，ピックそのものの研究もかなりなされたが，ピック については好条件の炭層であるので，たいした成果は得ていない。 当初第 2 図に示すようなチップ付ピックのみ使用していたが，そ の後チップ付は先端ドラムのみ, 本体ドラムにはチップなしで十 分稼動でき，経済的であるという結果を得ている。しかもこの後， オイルショックによる諸物価が高騰した時期であるが，第 3 四に 示すように, ピックのコストはむしろ低下をしている。この好条 件は, その後も継続したため, S49 年 にはチップ付は完全に中 止している。

しかし 51 年下期 ごろより炭層が薄層化してきたのが，いかな る条件でも従来通りの出炭量を確保するのが前提条件であるので

イ）切羽数を 2 切羽より 3 ，さらに 4 切羽とした。

口) 従つてドラムカッタの運転台数が倍加した。

八）一部下盤（硬い）切削しても稼行山丈の確保が必要である。

）切羽の進行を延すためドラム幅を広げた，したがつて一度 の使用量も増加した。

ホ）薄層化にともない一部硬炭化してきた。

以上の要因によりピックの

イ）使用量が増大した

口) 使用不能のもの，すなわち廃棄数が増大した

八）取扱い量の増加に伴い，管理上の問題も発生した

第1表カッターピック期別使用実績推移表

\begin{tabular}{|c|c|c|c|c|c|c|c|c|c|c|c|}
\hline 項目 期別 & $\begin{array}{r}1) \\
\text { 下/44 }\end{array}$ & 上/ 47 & 下/ 47 & 上 $/ 50$ & 下/ 50 & 上/ 51 & 下/51， & 上 $/ 52$ & $\begin{array}{c}22) \\
\text { 下/ } 52\end{array}$ & $\begin{array}{r}3 \\
\text { 上 } \\
53\end{array}$ & $\begin{array}{r}4) \\
\text { 下/ } 53\end{array}$ \\
\hline 使用本数 (本) & 23,678 & 41, 976 & 50,757 & 77,682 & 99,399 & 140,795 & 112,416 & 188,099 & 226,138 & 179, 908 & 194, 774 \\
\hline 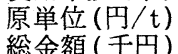 & $\begin{array}{r}55 \\
9332\end{array}$ & $\begin{array}{r}57 \\
32,715\end{array}$ & $\begin{array}{r}59 \\
40,166\end{array}$ & $\begin{array}{r}43 \\
34,650\end{array}$ & $\begin{array}{r}58 \\
45,168\end{array}$ & $\begin{array}{r}98 \\
70,069\end{array}$ & $\begin{array}{r}76 \\
66,392\end{array}$ & $\begin{array}{r}99 \\
93.204\end{array}$ & $\begin{array}{r}134 \\
113,694\end{array}$ & $\begin{array}{r}108 \\
98.210\end{array}$ & $\begin{array}{r}100 \\
93 \quad 965\end{array}$ \\
\hline 対象炭層 & 本層 & 上層 & 上 層 & 上 層 & 上, 層 & 上層 & 上層 & 上層 & 上 層 & 上 層 & 上層 \\
\hline
\end{tabular}

備考 1) 実績 3 力月分を 6 力月分に換算して計上 2) ピック使用を問題点として取上げる
3 ) 一部電子ビーム修理品を使用する

4) 1 月より全部電子ビーム修理品を使用する 
八）硬質溶接肉盛を行なう

2

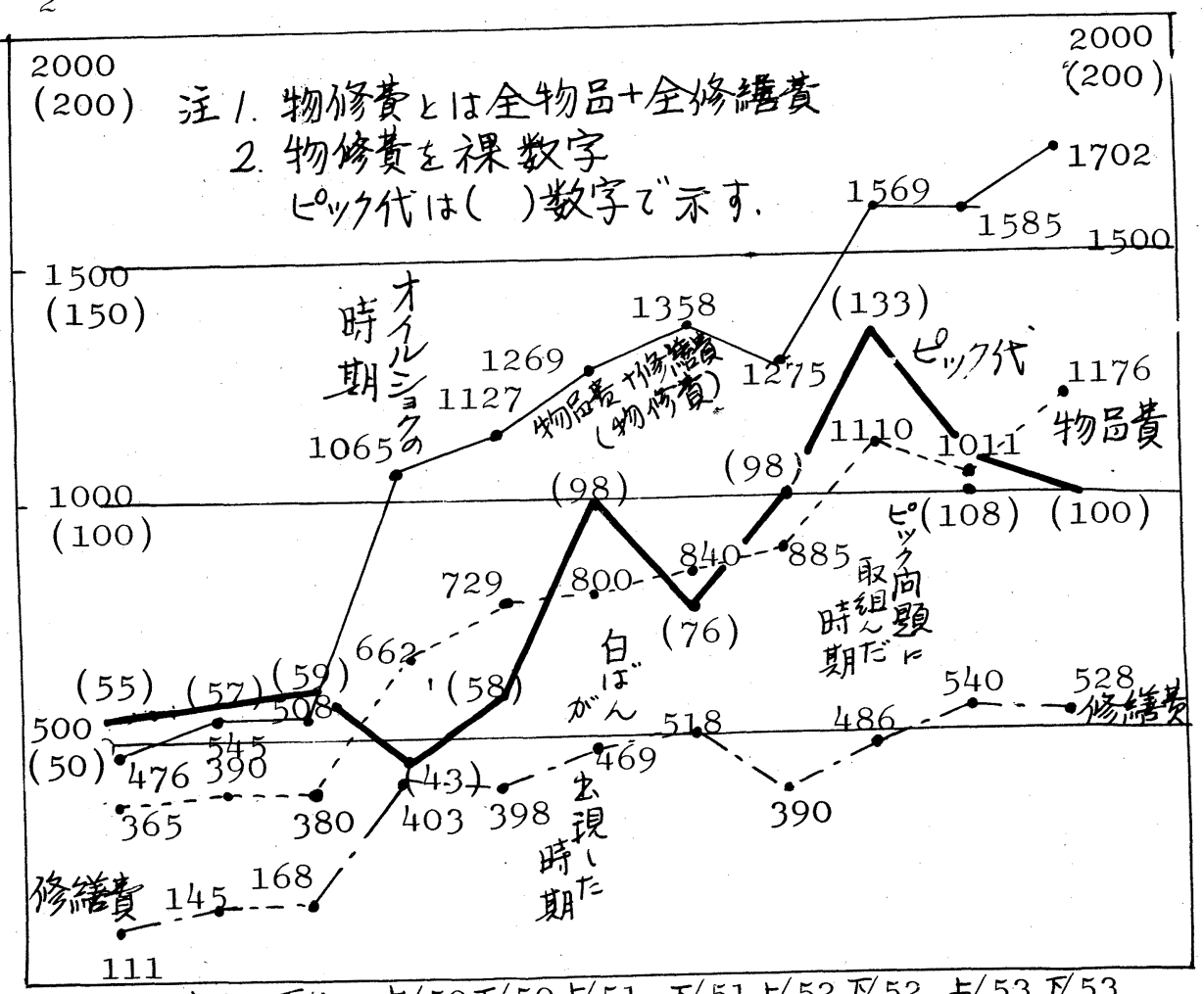

下/44上/47下/47 上/50下/50上/51 F/51上/52下/52 上/53T/53

年度. 期
ため鋭利な形状確保ができな い。

などの理由により異質の母材 同志を接合する方法, 例えば フラッシュバット法のような 接合はないものかと亀山ビッ 卜社に依頼したところ同社と

しても以上の目的以外の目的 （後述）も含め検討中であり， ユーザの協力を得られるなら 進めたいということになり， 後述の電子ビーム溶接法開発 に踏み出したのである。

初め試験品の接合部強度の チェックを行ない, 次の手順 で採炭現場に持ち込んだ。こ の場合最も苛酷な条件の切羽 で試験した。

$\mathrm{S} 52$ 年 11 月： 4 本試用

( 接合部の耐力)

$\mathrm{S} 53$ 年 1 月：自家製でレ

一儿鋼製， 300 本試用

$\mathrm{S} 53$ 年 2 月：82本（刃

先部コマの適性研究 一 第 2

表参照)

この試験結果，

イ）接合部の強度は異質の

第 3 図 出炭原価中の物修費とピック使用料との関係 (円/ $\mathrm{t}$ )

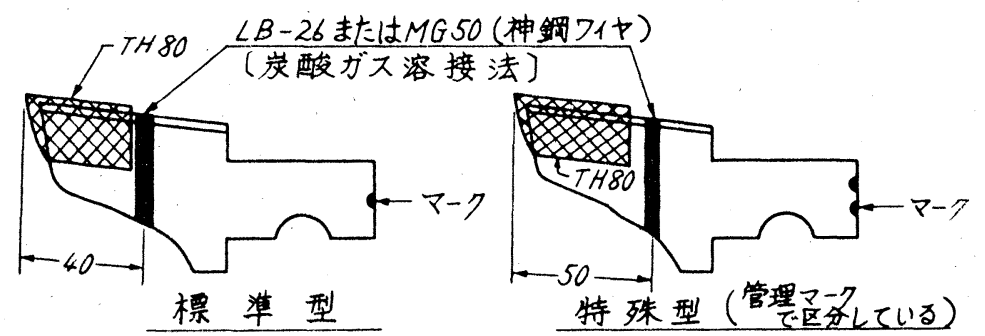

第 4 図 標準修理品と特殊修理品（単位：mm)

などの理由によりピックに対する技術改善の必要性が発生した。

\section{1) 廃棄品の再生}

使用後のピック修理再生に当つては経験等により刃先より 35 $\mathrm{mm}$ まで摩耗したもののみ第 4 図に示す標準品として刃先 $40 \mathrm{~mm}$ の切替修理を行なつてきたが，採炭現場での見きわめが困難でつ い使いすぎによる廃棄品が増大してきた。そこで，幾度かの現場 試験を経て特殊型と称する $45 \mathrm{~mm}$ 摩耗までの再生, 刃先 $50 \mathrm{~mm}$ 切 替まで実施し, 回収率を高めた。本修理品については溶接の精度 が要求されるため図示の如く管理マークで区分している。

\section{2) 修理方法の改善}

ピックは，その使用目的から材質を SCM-4 という特殊鋼を用 いている。この特性を生かすため刃先修理時の取替コマも同じ材 質を用い炭酸ガス溶接法により接合し，溶接棒はLB-26 を用い， 接合後, TH 80 で肉盛, 硬化していたが, この問題点は,

イ）溶接部の強度は母材部の $70 \sim 80 \%$ しか期待できない。

ロ）シャシク部と刃先部の材質変更ができない（目的が違うに もかかわらず, この改善のため硬質溶接肉盛を行なつていた）
おり，母材同志であるので絽返し修理も可能

ロ）刃先コマはやはりシャンク部と変えて使う力 が合理的である

八）可鍛性のあるマンガン鋼が経済的である という結果を得た。

$\mathrm{S} 53$ 年 4 月より, 刃先 $\mathrm{SMn}-3$, 修理品を毎日 100 本混用した。

$\mathrm{S} 53$ 年 6 月より東 3 片払は全数この修理品に切替 えた。その後逐次增加し, S 54 年1月より, 本修理 方法のみに変更した。

3) チップ付ピックの改善

当鉱の場合, 前述のようにチップ付ピックは導入当初採用し, その後，高価であるという理由で使用を中止していたが，S 52 年ごろ からの薄層, 下盤切削対策や硬炭部分採掘時は，発破による方法だ けでは大量出炭の確保ができず，チップなしピックではピック取 替量が多く，長時間を要するのでチップ付を再使用したところ， チップは摩耗するより久損による損耗の方が大であり，鋭利な文 先の確保もできず，効果を挙げることができなかつたので，第 5 図に示すように，さ、岩機用のチップを刃先に埋めこみ使用した ところ, 好成果を収めることができた。ただし本品はチップ自身, 高価であり, 加工方法に工数を要するので， 1 本当りの単価は標 準品の約 3 倍と非常に高価なものとなる，しかし後述の下盤切削 には好成果を挙げえた。

\section{3. 電子ビーム溶接法}

本溶接法について，亀山ビット社から提供してもらつた資料に よると，およそ第 5 図のような設備で，すでに，同社では特許出 
第2表 電子ビーム溶接ピック現場試験 （Ｓ53.2.1実施分）

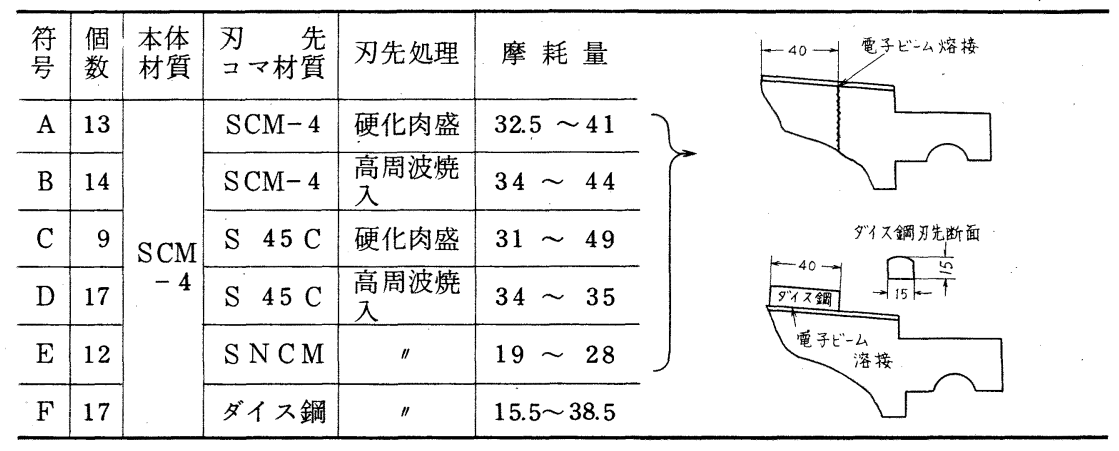

註 1. ダイス鋼は摩耗量はコマ外れのないもの

は少, 外れたものは大，6 個外れていた。

2. コマの接合方法に困難性あり

3. $\mathrm{A} \sim \mathrm{D}$ は大差ない

4. E流級材ですぐれている。

願準備中である。

真空中で, 特殊なフイラメントに高圧の電源を充電すると, 光 に近い速度で電子が空間にとびだす。これをコンデンサと収束レ ンズで収束すると, 微少な電子の束となる。これを電子銃（電子 ビーム)という。

これは熱線の束で, これを材料の微少な面積に衝突させると， 電子は表面層で停止し, そのエネルギーの $99 \%$ 以上が熱エネル ギーとなり, 高熱の微少な帯となつて金属を溶融着させる。これ が本溶接法の概要で, その特長は,

a) 電子ビームは, 極めて高いエネルギー密度が得られるので,

(1) 鉄やステンレス鋼は勿論のこと, タングステンやタンタル

のような高融点材料の溶接が可能

(口) 溶接ビーム幅に対して, 非常に高い溶け込みが得られる

( 後述の第 3 表参照)。

熱影響の狭い溶接ができるため, 金属結晶粒の粗大化が極 めて僅少である。

$\ominus$ 溶接部の変形が少なく, 歪の少ない精度の高い溶接ができ る。

b ) 電子ビームの発生源=電子銃は一種の電子管であるので,

(1) 簡単な操作により, 正確で自由な溶け込みが得られる。

(口) 作業者の個人差や技能の熟練は余り影響なく, 再現性のあ る溶接ができる。

極微小溶接から, 厚板溶接まで広範囲の溶接ができる。

c) 電子ビームは化学特性がなく, 溶接雲囲気は真空中である から,

(1) 活性材料の溶接が行なえる。

(口) 他の溶接法にはない脱ガス作用があるため, 高純度の溶接 ができる。アルゴンガスに比較して, 不純物の含有量は 1000 分 の 1 しかない。

溶接部が清浄に仕上がる

すなわち，a），b），c）をまとめると，

(1) 異種の材料を

(2) 熱影響を小さくし，

(3) 母材同志の正確な溶接を

(4) 変形させることなく，

(5) 特殊な技能員や操作する者の技能差の影響をうけないて,

(6) 衛生上よくないガスの発生もなく,

(7) あと熱処理するだけでよい……ものが得られることにな る。

そこで, 炭酸ガス溶接法と, 電子ビーム溶接法をまとめると,

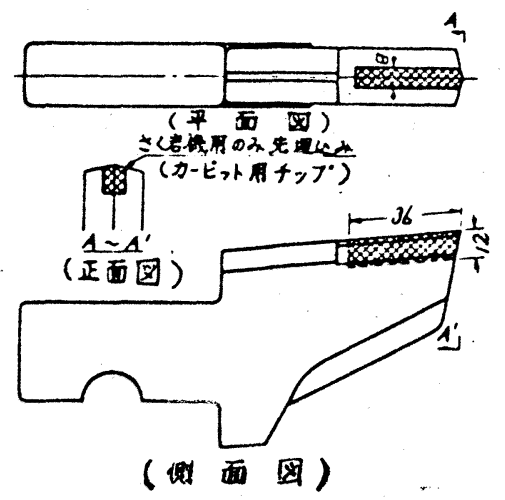

第 5 図 新型チップ付ピック (単位: $\mathrm{mm}$ )

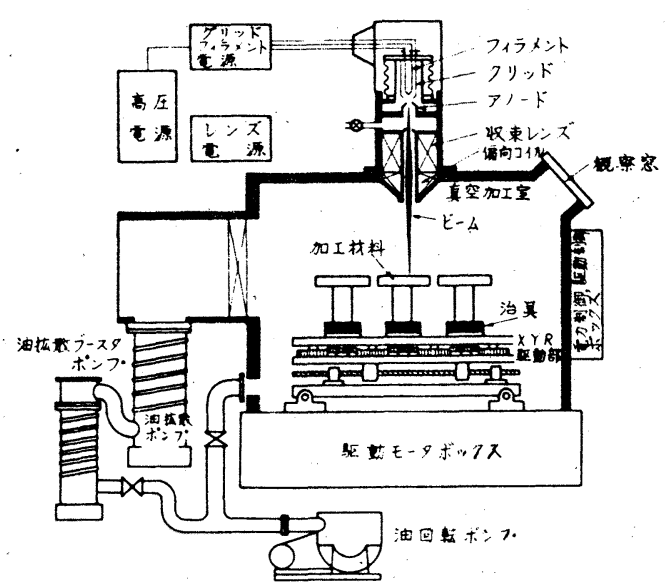

第 6 図 電子ビーム溶接機の構成図 第了表 アーク溶接法と電子ビーム溶接法の比較

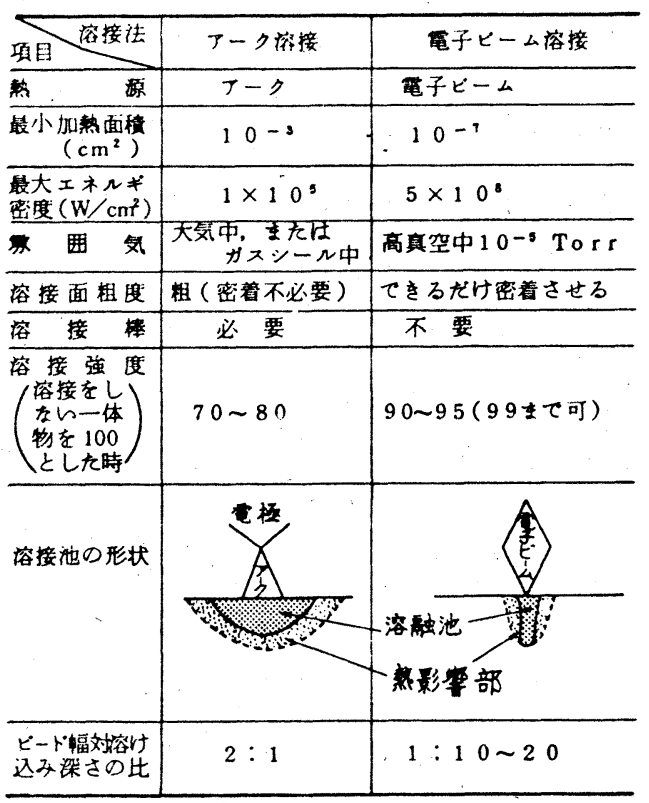

第 3 表のようになる。

一方，忺点がないわけでもなく，欠点をまとめると，次のよう なものがある。 
(1) 真空中で $\left(10^{-5}\right.$ の真空度 $)$ 作業するので, 手動作業ができ ないばかりでなく, 油脂・その他の付着物は真空度低下の要因と なるので,

(2) ショット，ブラストと，洗湺・乾燥に手間がかかる。

(3) 微少範囲の溶接であるので, 母材と刃先用コマそれぞれの 長さと位置ぎめが絶対条件である。...... 等が技術上克服しなけ ればならない問題である。

しかし，これ等は，一応メーカーサイドにまかせるとして，わ れわれ使用する立場からみると，前述の数多くの希望がかなえら れたことになる。

\section{4. 使 用 実 績}

1) $45 \mathrm{~mm}$ 修理品による利益

従来廃棄していたものの中から, 月平均 1,345 本再生という実 績であるので, 今後もこのような状況が持続するものと仮定し, 再生されたピックの残存価值の見方を一応, 新品価値から修理代 とシャンク部がすでに摩耗, 疲労し始めているので廃棄が早い, 等という減価を加味し，400円/本とみるなら月間 538 千円の利 益, 出炭コストへの影響は, 期産 90 万 $\mathrm{t}$ として利益 3228 千円/ 期, $t$ 当り 3.55 円 のコスト低減と計算される。

2）電子ビーム修理による利益

刃先部を S Mn-3 に変え, 高周波焼入による硬度確保により,

イ）常に鋭利な刃先が得られ，切削性がよくなつた。

ロ）母材同志の接合であるので, 繰返し修理が可能となつた。

八）接合部が小さい線になつているので，カッタマンの取替基 準がわかりよくなつた等，計算にのらない利益もあるが，一応使 用開始以来の実績を，各方面から累推すると，最低 $14 \%$ 以上は 節減できたものとみなされるので，金額で表すと 14 百万円/期 以上の利益, 出炭 $\mathrm{t}$ 当り 15.5 円 のコスト低減と計算される。

これらの成果の結集が，第 3 図によく表れている。

\section{3）下盤切削の実縝}

下盤に隆起盤が出現し，稼行山タケが確保できない時は，穿孔
発破による処理を行なつていたが, 150 本程度の発破作業実施に は約 90 分程度を要している。

この処理時間を短縮するため, カッタによる下盤切削も行なつ

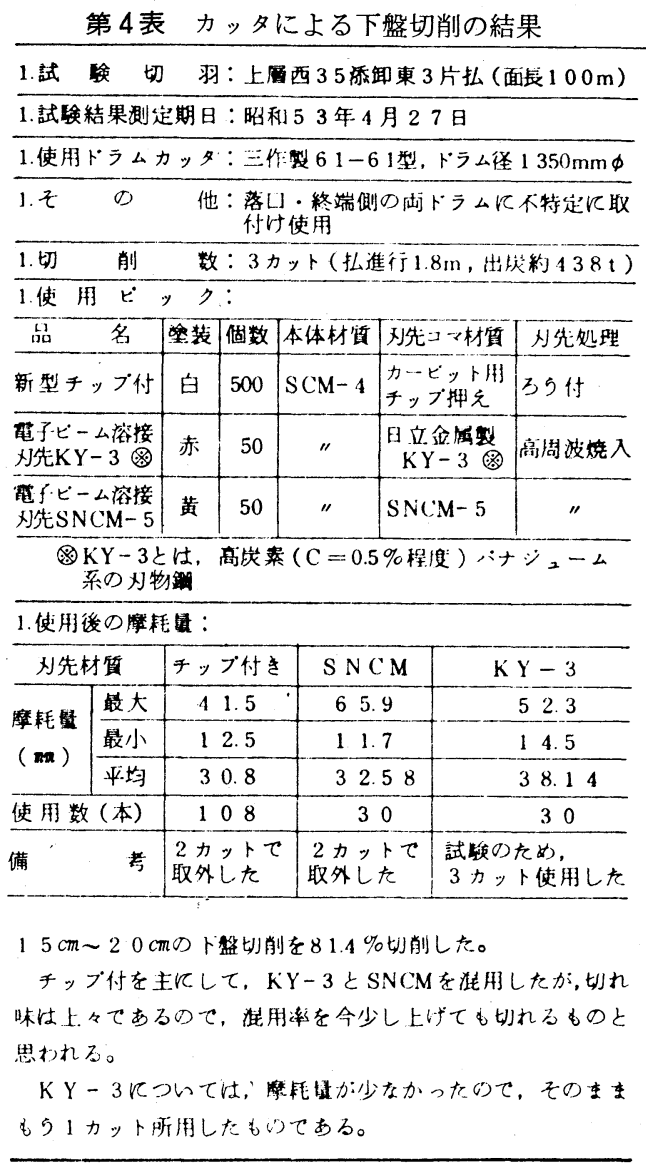

第 5 表 東 3 片払におけるカッタによる下艋切削採炭 ( 27 日と 28 日 1 番方) 前・後の状況 ( $S 53$ 年 4 月)

\begin{tabular}{|c|c|c|c|c|c|c|c|c|c|c|c|c|c|c|c|}
\hline 日 & \multicolumn{3}{|c|}{25 日 } & \multicolumn{3}{|c|}{264} & \multicolumn{3}{|c|}{$27 日$} & \multicolumn{3}{|c|}{28 日 } & \multicolumn{3}{|c|}{$29 \mathrm{E}$} \\
\hline 方 & 1 & 2 & 3 & 1 & 2 & 3 & 1 & 2 & 3 & 1 & 2 & 3 & 1 & 2 & 3 \\
\hline 炭 $(\mathrm{t})$ & 427 & 469 & 445 & 412 & 376 & 437 & 315 & 306 & 438 & 557 & 475 & 321 & 370 & 422 & 364 \\
\hline 配 役 数(人) & 16 & 17 & 14 & 17 & 14 & 14 & 17 & 15 & 12 & 15 & 14 & 13 & 14 & 14 & 12 \\
\hline 降起稳発破 $(\mathrm{m})$ & 56 & 54 & 34 & 54 & 44 & 57 & 22 & 25 & $15 A$ & 12 & 21 & 55 & 22 & 48 & 46 \\
\hline 火㮃使用量 (本) & 133 & 133 & 155 & 167 & 100 & 133 & 67 & 67 & 67 & 53 & 100 & 167 & 64 & 167 & 167 \\
\hline 下盤切削 & t & $ナ シ$ & ナシ & ナ シ & t * & ナシ & 切削 & 切削 & 切 削 & 切 削 & ナ & ナ シ & ナシ & ナシ & ナシ \\
\hline
\end{tabular}

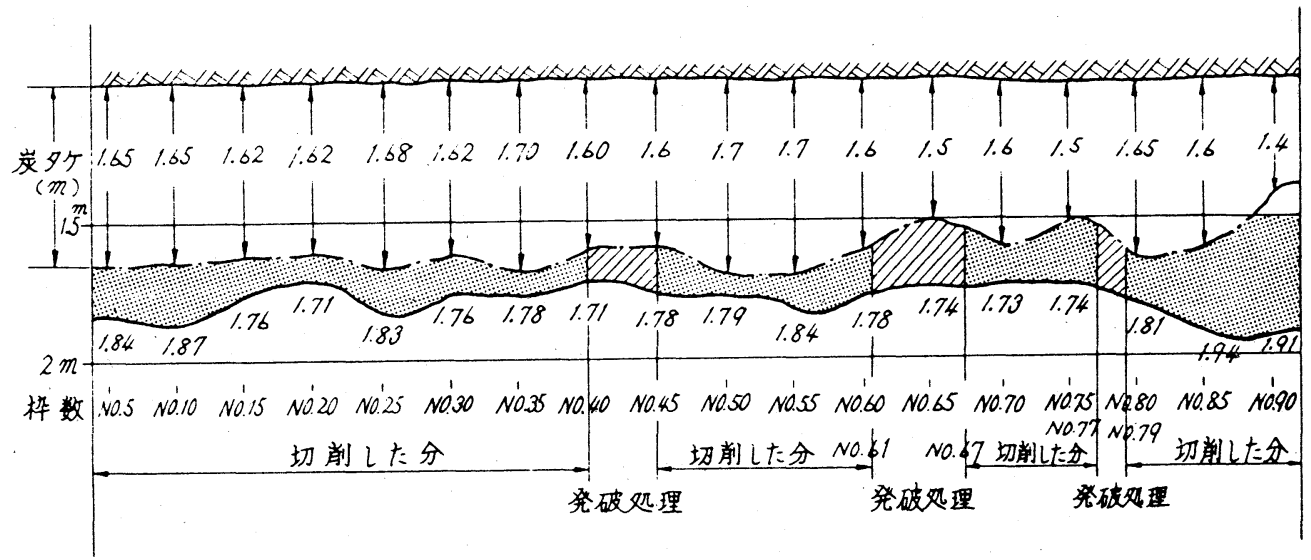

第 7 図

下般切削実績図

( $\mathrm{S} 53$ 年 4 月 27 日

3 番方分 )

( 単位: $m$ ) 
ているが, $S 53$ 年 4 月 27 日 3 番方〜 29 日 1 番方で, 特殊ピッ クによる下盤切削を実施したところ，発破所要時間を 60 分程度 まで短縮できた（第 4 〜第 5 表および第 7 図参照）。出炭とは直 結していないが，実際には付帯作業の影響であり，30 分は採炭 作業時間が確保できている。下盤の強度が $200 \mathrm{~kg} / \mathrm{cm}^{2}$ 以下であ れば可能で, この場合, 事前の試験を行なつてから実施した。

その後は, 特殊ピックを使用しなくとも，50〜 $100 \mathrm{~mm}$ の下 盤切削は，必要に応じて実施している。

下盤発破作業は, 出炭面だけでなく, 保安面や採炭員の出勤意 欲など，計算にのらない利益も多分に認められる。

\section{5.むすび}

自然を相手に未知のフイルドに埋蔵されている石炭を採掘する 任務にたずさわつている我々としては, 自然条件の変化をあらゆ る方法で予知し，その条件の中で, 保安を確保しながら出炭確保
につとめているが，コストの低減への努力も大切な責務である。 ここではカッタピックについて, 電子ビームによる修理方法の 改善や, 新たな良材質ピックの使用ができ, コスト低隇すること ができたが, まだ 100 円/ $\mathrm{t}$ 以上のコストとなつているので, 使 用方法や管理面, さらには安価で刃先材に適する材料を開拓する などの努力により, 一部では, 下盤切削を実施してもなお 60 円/ $\mathrm{t}$ までくらいの低減を四りたいものである。

さらには, カッタピックにとどまることなく, 出炭原価に大き なウェイトを占める, 坑木, 火薬, 機工備品などの物品費をはじ め, 修繥費; 労務費, 電力費, その他あらゆるものに対して, 広 範な問題意識をもち, 技術面と管理面から, 一つ一つ前向きに対 処し，安価な石炭への努力を傾注することが責務と考えている。

最後に, 担当者として, 亀山ビット社の協力に対し, 感謝の意 を表する次第である。

〔一般 講 演〕

(5) TWO GATE 方式による長面長切羽について

太平洋炭矿 (株) 釧路鉱業所 西 尾 竜一

\section{1. まえがき}

当鉱は, 北海道東部釧路市に位置し, 純然たる一般炭のみを産 出する海底炭砇である。

本年 4 月から鉱業所制度に復し, 稼行区域を中央坑, 益浦坑に 二分し, 生産を継続している。

当鉣では昭和 42 年よりシールド枠とドラムカッタを組合わせ たいわゆる“S D採炭”を面長 $35 \mathrm{~m}$ から発足させ, 爾後面長の 逐次増大並びに枠の改良, ゲート運炭設備の改善, その他諸々の 技術開発, 改善を重ねて成果を挙げ, 厳しい石炭情勢を乗り切つ て今日まで過してきた。

今回従来の S D 切羽とは全く型式の異なつた長面長切羽 ( 230 $\mathrm{m}$, 両サイドに運炭路を持つTwo Gate 方式) を昭和 53 年 11 月 から稼働させ，相応の実績を得ることができたので，その概要を 報告し御批判を仰ぐ次第である。

\section{2. 発想の経緯}

出炭コストに占める坑道費用の割合は非常に大きなものであり この低減のためにはできる限り大型の切羽が望ましく, それがさ らには掘進の余裕に繋がるわけである。

当鉱においては沿層坑道は総てコンティニアスマイナー（以後 C M と記す) で行なつており, 採炭準備の坑道展開に余裕のでき ることは C M S D 切羽では採掘不可能な区域, 例えば断層に田 まれた三角区域等において柱房式採炭（以後ルーム採炭と記す） に使用することが可能となり，そのメリットは計り知れないもの がある。

当矿では 52 年度下期より軽合金製の梁 (長さ $5.0 \mathrm{~m}$ ) と鉄柱 を使用する新しいルーム採炭を行なつており，CM 1 台で $500 \mathrm{t}$ /日の実績を挙げている。

現在当砇では, このルームの出炭比率を高めることが生産工の 大きな目標となつており，そのための諸方策を実施中である。

このため, 数に限りのある C Mを有効に使用してルームに振り
向けるには, S D 切羽の準備掘進を可能な限り少なくすることが 必要になつてくる。

このため, 当砇ではフィールドの許す限り, かつ機械的能力の 範囲内で大型切羽の設定を指向する方針を採つた。

当初 $35 \mathrm{~m}$ で出発した S D 切羽は逐次面長増大し標準面長 100 $\mathrm{m}$ で長い間推移してきたが, 昨年 $150 \mathrm{~m}, 180 \mathrm{~m}$ の切羽に挑戦し 十分やれることを立証した。

この $180 \mathrm{~m}$ 切羽稼働の経験から面長増大も現有設備では, これ が限界でこれ以上は無理と考えている。これ以上の面長増大を望 むならば設備の大型化, 大容量化が必要であり, しかしそれはそ の投資額に比較して得る効果はさほど大きなものは期待できない と考えている。

今回発表する南益浦上層西 3 片 1 号 S D は断層と払跡に囲まれ た従来の考え方では $100 \mathrm{~m}$ 切羽を $20 \mathrm{~m}$ の炭柱を残して 2 面採掘 すべきフィールドを先に述べた観点からなんとか一面で採掘した いという構想のもとに計画したものである。

この計画の内容は

（i）坑道の掘進長を減少させる。 $(\triangle 900 \mathrm{~m} \times 2=1800 \mathrm{~m})$

(ii) 従来の坑道保護炭柱も採掘する。（実收率 up $200 \mathrm{~m}$ に対 (20m)

(iii) 現有の設備を利用して行なう。（従来方式では $180 \mathrm{~m}$ が限 界)

（V） 日々の出炭量を増大させる。（集約採炭）

(V) 単位出炭量当りの工数減。(直接, 間接工数減)

を満足させることに主眼を置いて検討した結果, 入排気坑道両方 に運炭路を持ち切羽中央で P C リタン部を結合させ, カッタ 2 台 を配置し, 左右両側へ別々に炭を出す長面長の切羽を設定した。

この切羽は 1 本の切羽であるが設備は 2 切羽分という恰好であ るから左右の自走枠, P Cトラフ, カッタ等は同じものを備える 必要は全くなく, 異型のものであつても一向に差し支えないので ある。

このため全鉣的に見ても機器のやり繰りが楽であり, 同一種類 